\title{
Food safety and quality of distribution of raw human milk from a University Hospital
}

\section{Segurança alimentar e qualidade da distribuição do leite humano cru de um Hospital Universitário}

\author{
Marina Aparecida da Silva MORENO'1 (D) 0000-0002-9566-1551 \\ Lucíola Sant'Anna de CASTRO² (iD) 0000-0001-9729-8306 \\ Ana Cristina Freitas de Vilhena ABRÃO ${ }^{1}$ (iD) 0000-0001-6249-2467 \\ Kelly Pereira COCA ${ }^{1}$ (D) 0000-0002-3604-852X
}

\section{A B S T R A C T}

\section{Objective}

To evaluate the quality of raw human milk distributed in the Neonatal Intensive Care Unit of a University Hospital of the city of São Paulo.

\section{Methods}

A cross-sectional study with raw human milk samples from mothers who attended the Human Milk Collection Station of a University Hospital, analyzed between May 2016 and January 2017, excluding mothers of twins. The quality of the raw human milk was assessed by verifying the presence of dirt, the coloration of the milk, the titratable acidity using the Dornic method, and through its energy content. Kruskal-Wallis and Mann-Whitney

\footnotetext{
${ }^{1}$ Universidade Federal de São Paulo, Escola Paulista de Enfermagem, Departamento de Enfermagem na Saúde da Mulher. R. Napoleão de Barros, 754, $3^{\circ}$ andar, Vila Clementino, 04024-002, São Paulo, SP, Brasil. Correspondência para/Correspondence to: KP COCA. E-mail: <kcoca@unifesp.br>.

2 Universidade Federal de São Paulo, Escola Paulista de Medicina, Departamento de Medicina Preventiva. São Paulo, SP, Brasil.

Support: MASM was granted a research scholarship from the Conselho Nacional de Desenvolvimento Científico e Tecnológico (CNPq, National Council of Scientific and Technological Development) through the Institutional Scholarship Program by UNIFESP (2015-2017).
}

Como citar este artigo/How to cite this article

Moreno MAS, Castro LS, Abrão ACFV, Coca KP. Food safety and quality of distribution of raw human milk from a University Hospital. Rev Nutr. 2018;31(6):547-56. http://dx.doi.org/10.1590/1678-98652018000600004 
tests were used for the analysis of the energy profile and the degree of Dornic acidity, according to the stage of the raw human milk and the gestational age of the child.

\section{Results}

The study was composed of 40 samples of 40 different women, with a mean age of 27 years, an average of 11.8 years of education, most of them were multiparous and with a partner. Regarding milk analysis, $55.0 \%$ was classified as colostrum, $27.5 \%$ as mature milk and $17.5 \%$ as transitional milk. All samples presented negative results for dirt and normal coloration. The mean milk acidity was $3.24^{\circ}$ Dornic and most of the samples were classified as hypercaloric energy content. There was no association between the lactation stage and gestational age with the acidity value and energy content.

\section{Conclusion}

The quality of raw human milk distributed in the Neonatal Intensive Care Unit of the institution evaluated was considered adequate and the samples analyzed had a high energy content and excellent Dornic acidity.

Keywords: Food and Nutrition Security. Human milk. Milk Banks. Premature Infant.

\section{RE S U M O}

\section{Objetivo}

Avaliar a qualidade do leite humano cru distribuído para a Unidade de Terapia Intensiva Neonatal de um Hospital Universitário do município de São Paulo.

\section{Métodos}

Estudo transversal com alíquotas de leite humano cru de mães que frequentaram o Posto de Coleta de Leite Humano de um Hospital Universitário, analisadas entre maio de 2016 a janeiro de 2017, sendo excluídas alíquotas de mães de gêmeos. Verificou-se a qualidade do Leite Humano Cru pela presença de sujidade, coloração, acidez titulável pelo Método Dornic e conteúdo energético. Empregou-se os testes Kruskal-Wallis e Mann-Whitney para as análises do perfil energético e do grau de acidez Dornic, segundo estágio do Leite Humano Cru e idade gestacional da criança.

\section{Resultados}

A pesquisa foi composta por 40 alíquotas de 40 mulheres diferentes, com média de idade de 27 anos, 11,8 anos de estudos, a maioria multíparas e com companheiro. Quanto à análise do leite, 55,0\% foi classificado em colostro, 27,5\% em leite maduro e 17,5\% em leite de transição. A totalidade das alíquotas apresentou resultado negativo para a avaliação de sujidade e com coloração normal. A média da acidez do leite foi de 3,24 Dornic e a maioria das amostras foi classificada como perfil energético hipercalórico. Não foi observada associação entre o estágio de lactação e idade gestacional com o valor da acidez e conteúdo energético.

\section{Conclusão}

A qualidade do leite humano cru distribuído na Unidade de Terapia Intensiva Neonatal da instituição avaliada foi considerada adequada sendo as amostras analisadas com alto conteúdo energético e grau de acidez Dornic excelente.

Palavras-chave: Segurança Alimentar e Nutricional. Leite Humano. Banco de Leite Humano. Recém-nascido Prematuro.

\section{NTRO D U C T I O N}

Food and Nutrition Security (FNS) is defined in Brazil by the Lei Orgânica de Segurança Alimentar e Nutricional (LOSAN, Organic Law of Food and Nutrition Security - No.11.346, of July $15,2006)$ as the "realization of the right of all to regular and permanent access to quality food in enough quantities, without compromising access to other essential needs, based on health-promoting food practices that respect cultural diversity and are socially, economically and environmentally sustainable" [1]. However, the use of this concept differs in practice for each area involved in FNS, so that defining a conceptual framework on the problem to be 
studied can be an effective tool for the orientation of public policies [2].

Regarding eating habits for children, the World Health Organization recommends exclusive breastfeeding until 6 months of age with no liquids other than breast milk, and continue breastfeeding with appropriate supplementary food until two years of age or older [3], given the numerous mutual motherbaby benefits, such as lower risk of postpartum hemorrhage, anemia, breast cancer, and improved metabolic parameters in women; and reduction of occurrences of respiratory, gastrointestinal, sudden death and necrotizing enterocolitis in children [4-7].

However, the limitations of preterm and/ or hospitalized infants in the Neonatal Intensive Care Unit (NICU) are challenges to be faced in order to allow the initiation and continuation of breastfeeding $[8,9]$. In this perspective, the Human Milk Bank (HMB) has been a strategic policy to support and promote breastfeeding, which enables the offer and guides the supply of pasteurized and Raw Human Milk (rHM) in order to enable breastfeeding among these children [10].

The objective of the HMB is to promote and protect breastfeeding and to ensure the quality of the whole process of collection and distribution of Human Milk (HM) to reduce infant mortality [10]. Due to the benefits of rHM supply, pasteurized HM is only recommended for children who have been admitted to a NICU in cases where their mother's raw milk is not available, with infant formula being the last food of choice [11].

Thus, the quality control of rHM offered to children hospitalized in NICU has a direct impact on their benefit, since, for example, acidification of milk may lead to a decrease in the bioavailability of calcium and phosphorus and immunological factors [12]. Likewise, the low energy content of $\mathrm{HM}$ results in a loss of adequate weight gain, and even more serious, the occurrence of contamination during collection may make it inappropriate for consumption [13].
One way to ensure FNS for these children is through the standardization of norms and routines stipulated by the Brazilian Network of Human Milk Banks (rHMB-Br), a reference for several countries in the world, in which donated milk is evaluated before being pasteurized and rHM is extracted in a suitable environment to be offered from the mother to the child $[10,14]$. However, studies demonstrating the quality of rHM are scarce in the literature.

Thus, the objective of this study was to evaluate the quality of raw human milk distributed in the Neonatal Intensive Care Unit of a University Hospital of the city of São Paulo.

\section{METHODS}

This is a cross-sectional, observational study with data collected routinely at the Human Milk Collection Station (HMCS) of the HMB at the University Hospital of the Universidade Federal de São Paulo (UH-UNIFESP, University Hospital of the Federal University of São Paulo), from May 2016 to January 2017. The UH-UNIFESP is a reference institution for women in the South Region of the city of São Paulo.

Included in the study were samples of $\mathrm{rHM}$ donated by nursing mothers who attended the HMCS for milk extraction and thus providing breast milk to their hospitalized child at the NICU, who signed the Free and Informed Consent Form (ICF) (Figure 1).

The following data were collected from the mothers and their infants by face-to-face interviews: age, education, presence of the partner, parity, number of prenatal appointments, type of delivery and postpartum days to identify the lactation stage of the woman; and of the child: gender, Gestational Age (GA) and birth weight. The GA variable was categorized as: full-term newborns ( $G A>37$ completed weeks), moderate preterm $(\mathrm{GA}<37$ incomplete and $>32$ completed weeks), very preterm (<32 incomplete and $>28$ completed weeks), and 


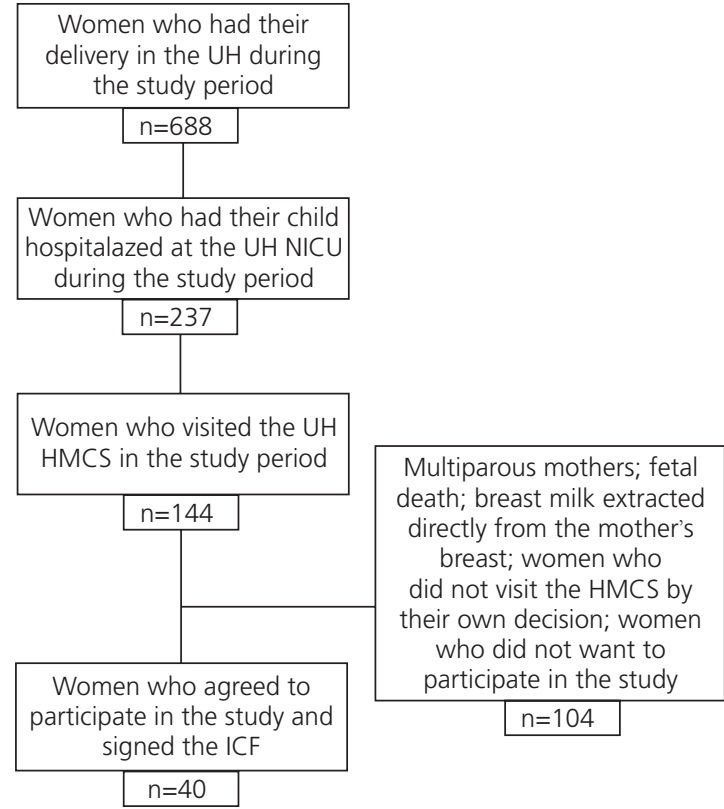

Figure 1. Flowchart of the study sample. São Paulo (SP), Brazil, 2016/17.

Note: UH: University Hospital; NICU: Neonatal Intensive Care Unit; HMCS: Human Milk Collection Station; ICF: Inform Consent Form.

extremely preterm ( $\mathrm{IG}<28$ incomplete weeks) [15]. To identify the different stages of lactation, the rHM was characterized in: colostrum ( 0 to 7 days postpartum), transitional (8 to 14 days postpartum) and mature ( 15 days postpartum or longer).

Samples were collected in the afternoon at the HMCS, immediately after the mother had provided this milk sample. All women in the study followed the standard HMCS routine: wrapped hair, wearing a disposable hair net, a mask and an apron, with their hands washed and sanitized breasts with gauze soaked in physiological solution $(0.9 \%)$ immediately prior to the extraction of milk $[10,14]$. Then they received a sterile vial and connectors for the extraction of milk from both breasts, by means of electric pump, from the brand Medela ${ }^{\circledR}$ (Lactina model, Baar, Switzerland), for 30 minutes. At the end of the procedure, a professional responsible for the HMCS collected a $5 \mathrm{~mL}$ sample with a disposable sterile syringe, placing it in a glass test tube. Together with this professional, a researcher evaluated the presence of dirt and the color of the freshly extracted human milk. Subsequently, the $5 \mathrm{~mL}$ sample was redistributed in 3 other $1 \mathrm{~mL}$ test tubes each for acidity analysis and the remaining $2 \mathrm{~mL}$ in three capillary tubes for energy content analysis. All analyzes were performed in the HMCS, shortly after sample collection.

The quality of the rHM was evaluated by verifying the presence of dirt, the coloration of the milk, the titratable acidity using the Dornic method $\left({ }^{\circ} \mathrm{D}\right)$, and through its energy content $[10,14]$. Dirt was defined as the presence of hair and/or lint after the milk extraction. White and yellow colors were considered as normal or suitable colors of human milk, while the colors "brick red" and dark green were considered as abnormal or inadequate, and milk should be discarded [10]. To determine the titratable acidity, a Dornic acidometer (EME Equipment ${ }^{\circledR}$, São Paulo, Brazil) graduated of $0.01 \mathrm{~mL}$, a standard $0.1 \mathrm{~N}$ sodium hydroxide solution and a solution of $1 \%$ hydroalcoholic phenolphthalein in $95^{\circ} \mathrm{GL}$ alcohol (ninety-five degrees Gay-Lussac) neutralized [13], and values between 1 and $8^{\circ} \mathrm{D}$ were considered appropriate for the classification $[10,14]$.

For the analysis of energy content, the Crematocrit method was used, which consisted of centrifuging the HM samples in a Fanem Century ${ }^{\circledR}$ Centrifuge (São Paulo, Brazil), followed by measuring the cream column with a ruler of $20 \mathrm{~cm}$ with subdivisions of 1 millimeter, and calculating the energy value with the formula: Energy content $=[\%$ of cream (cream column in $\mathrm{mmx100/total} \mathrm{column} \mathrm{in} \mathrm{mm)x66.8+290]=Kcal/L}$ $[10,14]$. In order to classify the energy content, milk samples were considered as: hypocaloric (<500Kcal/L), normocaloric (500 to $700 \mathrm{Kcal} / \mathrm{L}$ ) and hypercaloric $(>700 \mathrm{Kcal} / \mathrm{L})[16,17]$. Both the Dornic acidity and the crematocrit value were obtained by calculating the mean value of the three individual samples (in triplicate).

As a secondary endpoint, the HM stage and the GA of the child were compared with the acidity and energy profile values. The sample was obtained for convenience. In the 
data description measures of central tendency (mean) and dispersion (standard deviation, minimum and maximum values) were used for quantitative variables and relative and absolute frequencies for those of a qualitative nature. The non-parametric Kruskal-Wallis and Mann-Whitney statistics were used in the analyzes of the endpoints (energy content and degree of Dornic acidity), the second stage of the rHM and the GA of the child, considering the level of significance a equal to $5 \%$. The statistical software Stata (Statistical Software for Professionals, StataCorp, College Station, Texas, United States of America), version 10.0, was used in data analysis.

The study complied with Resolution No.466/12 of the National Health Council, and was submitted and approved by the Ethics Committee of the Federal University of São Paulo, Protocol No.1.517.396, after authorization from the Teaching and Research Commission of the UH-UNIFESP.

\section{R E S U L T S}

The research was composed of 40 samples from 40 women, with a mean age of 27 years, 11.8 years of education, the majority of them multiparous and with a partner. The newborns had a mean gestational age of 34 weeks, mean birth weight of 2,333.8 grams, most of them were classified as moderate preterm cases and were equally divided between the sexes (Table 1).

Most of the analyzed samples were classified as colostrum. Regarding the analysis of the presence of dirt, all samples were negative; in relation to the colors, all were evaluated as adequate. The mean Dornic acidity score was $3.2^{\circ}$ and all samples were classified as adequate.

Figure 2 shows the distribution of the degree of Dornic Acidity among the samples analyzed. Most of the samples had a hypercaloric profile, with a mean of $764.2 \mathrm{Kcal} / \mathrm{L}$ (Table 2 ).

Although the mean energy content was higher in the samples collected from mothers

Table 1. Characterization of the studied population. São Paulo (SP), Brazil, 2016/17.

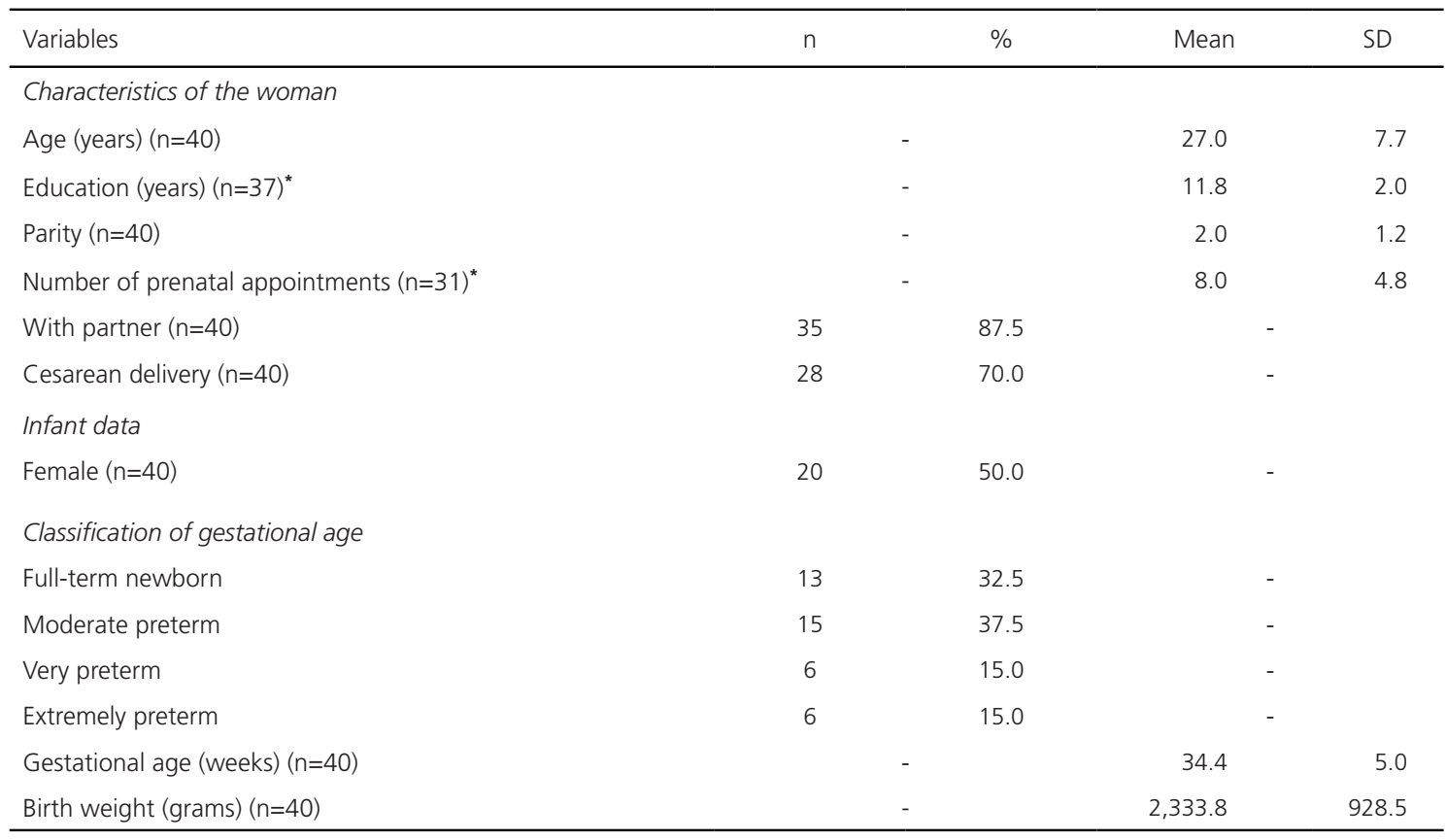

Note: *Sample variation due to data loss.

SD: Standard Deviation. 


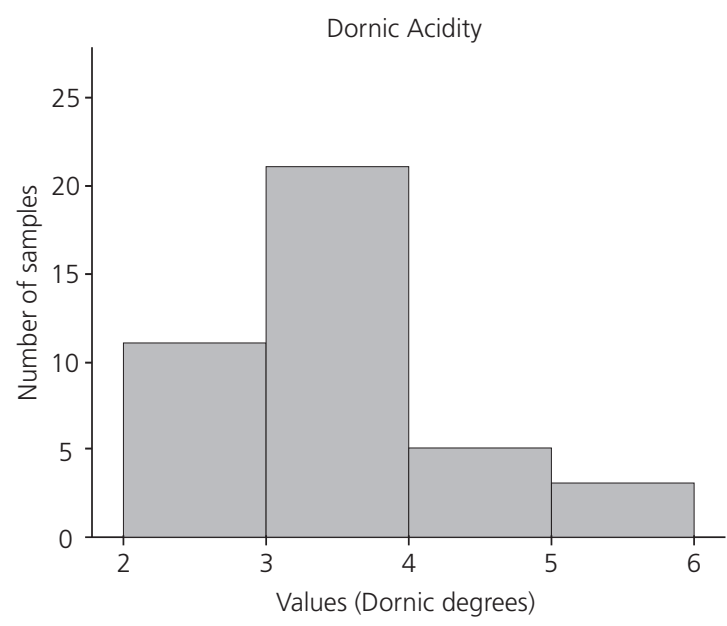

Figure 2. Distribution of the degrees of Dornic acidity ( $\left.{ }^{\circ} \mathrm{D}\right)$ by the number of samples analyzed. São Paulo (SP), Brazil, 2016/17.

whose children were preterm $(830.2 \mathrm{Kcal} / \mathrm{L})$, there was no statistically significant difference (Table 3) when compared to full-term mothers (704.6Kcal/L). There were no statistically significant differences between the different stages of HM and the degree of Dornic acidity and energy content of the milk, nor was there any difference between the GA of the child and the values of acidity and energy content (Table 3 ).

\section{DISCUSSION}

Preserving the characteristics of $\mathrm{rHM}$ distributed to hospitalized children is critical to obtaining all the benefits of breastfeeding and ensuring child food security.

According to the standards of the Brazilian National Health Surveillance Agency, the extraction of $\mathrm{HM}$ can be done in a $\mathrm{HMB}$ or a HMCS, since they are considered indicators of milk quality control. In 2018, rHMB-Br introduced a technical standard that deals with the use of exclusive rHM in Neonatal environments, aiming to guide the procedures that ensure the biological quality of the milk offered and, consequently, FNS of children [18]. Milk extraction in an inappropriate environment may increase the risk of contamination and the presence of foreign odors, as well as non-

Table 2. Analysis of raw human milk samples according to their characteristics and quality evaluation. São Paulo (SP), Brazil, $2016 / 17$.

\begin{tabular}{|c|c|c|c|c|}
\hline Human milk variable & $\mathrm{n}$ & $\%$ & Mean (SD) & Min-Max \\
\hline \multicolumn{5}{|l|}{ Classification $(n=40)$} \\
\hline Colostrum & 22 & 55.0 & & - \\
\hline Transitional & 7 & 17.5 & & - \\
\hline Mature & 11 & 27.5 & & - \\
\hline Presence of dirt $(n=40)$ & 0 & 0 & & - \\
\hline \multicolumn{5}{|l|}{ Color $(n=40)$} \\
\hline Yellow & 17 & 42.5 & & \\
\hline Whitish & 23 & 57.5 & & - \\
\hline "Brick red" & 0 & 0 & & - \\
\hline \multicolumn{5}{|l|}{ Energy profile $(n=40)$} \\
\hline Hypocaloric & 6 & 15.0 & & - \\
\hline Caloric & 13 & 32.5 & & - \\
\hline Hypercaloric & 21 & 52.5 & & - \\
\hline Degree of Dornic acidity $(n=39)^{*}$ & & & $3.2(0.8)$ & $2.1-5.6$ \\
\hline Energy value $(\mathrm{Kcal} / \mathrm{L})(\mathrm{n}=40)$ & & & $764.2(237.0)$ & $387.1-1,769.6$ \\
\hline
\end{tabular}

Note: *Sample variation due to data loss.

SD: Standard Deviation. 
Table 3. Mean and Standard Deviation (SD) of milk acidity (Dornic degrees) and energy content (Kcal/L) of raw human milk samples, according to the stage of lactation and gestational age. São Paulo (SP), Brazil, 2016/17.

\begin{tabular}{|c|c|c|c|c|c|c|}
\hline \multirow{2}{*}{ Variable } & \multicolumn{3}{|c|}{ Dornic acidity } & \multicolumn{3}{|c|}{ Energy content (Kcal/L) } \\
\hline & Mean & SD & $p$ & Mean & SD & $p$ \\
\hline \multicolumn{7}{|c|}{ Stage of lactation } \\
\hline Colostrum & 3.3 & 0.9 & $0.614^{*}$ & 703.3 & 155.9 & $0.109^{*}$ \\
\hline Transitional & 3.0 & 0.4 & & 853.5 & 138.4 & \\
\hline Mature & 3.5 & 1.1 & & 820.3 & 447.7 & \\
\hline \multicolumn{7}{|c|}{ Gestational Age } \\
\hline Preterm & 3.2 & 0.8 & $0.830^{* *}$ & 830.2 & 296.5 & $0.180^{* *}$ \\
\hline Full-Term & 3.3 & 0.8 & & 704.6 & 163.1 & \\
\hline
\end{tabular}

Note: ${ }^{*}$ Kruskal-Wallis test $(p<0.05) ;{ }^{* *}$ Mann-Whitney test $(p<0.05)$.

SD: Standard deviation.

compliance with hygiene and sanitary standards [10]. In this study, no samples analyzed showed dirt, which demonstrates compliance with the established standards.

As for the coloration of HM, performed with the naked eye, it was observed that the samples varied between yellow and white, that is, they were adequate. The variation occurs according to the predominance of the constituents of a certain fraction of the milk. Colostrum has shades of yellow-orange due to the presence of carotene. The transition milk will gradually change to a bluish/opaque white color. Mature milk may have its color altered according to the diet of the nursing mother or by the use of medications, for example, milk with a greenish coloration due to a diet rich in riboflavin $[10,16]$. The "dark green" coloration is caused by the bacterium of the genus Pseudomonas, and the "brick red" coloration, may be due to the suspicion of blood in the milk by papillary discharge or nipple injury, or by the presence of the bacterium Serratia marcescens, making such sample unfit for human consumption [10], since this bacterium has been the causative agent of infections in children hospitalized in NICU [19]. In a study that investigated an outbreak of Serratia marcescens in an NICU in Turkey, it suggested the possibility of contamination through $\mathrm{rHM}$, although it was not statistically correlated
[19]. This research was not aimed at analyzing possible strains in rHM samples but identifying and eliminate possible contamination risks by changes in rHM colors.

In relation to the acidity, the $\mathrm{HM}$ has a natural acidity, which varies between 1.0 and $4.0^{\circ} \mathrm{D}$. This acidity, practically free of lactic acid, results from the presence of milk constituents such as casein micelles, mineral salts and whey proteins. The acidity developed is due to the lactic acid which is produced from the bacterial growth related to external contamination, such as contaminated hands and tools $[10,13]$. In addition to raising the acidity of $\mathrm{HM}$, the production of lactic acid contributes to the non-absorption of calcium and phosphorus $[13,20,21]$. Despite the increase in the acidity of human milk, by being exposed to the environment after extracted, is considered as quality value $\leq 8$ by the Dornic Method [10].

The Dornic Method is a simple and convenient test to identify the quality of $\mathrm{HM}$ in relation to the presence of developed acidity and its correlation with bacterial growth [22].

All the samples of rHM analyzed presented an acidity value within the normal parameters, being the majority below $4^{\circ} \mathrm{D}$, suggesting that the manipulation of the $\mathrm{HM}$ during the extraction was carried out properly, allowing the maintenance of the original acidity 
of the milk and preserving the quality. At the institution in question, milk samples are labeled and immediately packaged in a refrigerator with a temperature below $5^{\circ} \mathrm{C}$, avoiding the development of microorganisms in the milk, and consequently, maintaining the quality of the extracted rHM. A study analyzed the effect of storage on the acidity of $\mathrm{rHM}$ (in a refrigerator at $5^{\circ} \mathrm{C}$ after 12 hours and in a freezer at $-20^{\circ} \mathrm{C}$ after 15 days), showed that $80 \%$ of the sample preserved the acidity of the milk in the different periods of storage in a refrigerator [23].

One study observed that the higher the acidity, the greater the contamination of the milk by microorganisms [13]. In this way, the importance of ensuring the quality of milk at the time of its extraction is emphasized, as well as the exposure time of rHM at room temperature, considering the possibility of bacterial proliferation and, consequently, a high level of Dornic acidity. The determination of rHM exposure time to the environment is controversial, whereas in Brazil it is standardized in one hour, in Australia the recommended time is up to four hours $[24,25]$. Thus, the value of the degree of acidity found in this study can be a guide for new studies that intend to extend this period and even discuss the use of the Dornic method as a possible alternative in cases of doubt regarding the quality of milk to be offered raw, avoiding unnecessary contempt.

With regard to the energy content, this study identified the predominance of hypercaloric milk, guaranteeing the nutritional safety of the child. Hypercaloric milk is of fundamental importance for preterm and/or low birth weight babies, favoring weight gain and minimizing rates of infant morbidity and mortality. The energy content of HM varies according to the proportion of the presence of its constituents, considering the stage of lactation and GA [10]. In addition, maternal age, gestational diabetes, and high postpartum maternal Body Mass Index (BMI) levels may also be related to the macronutrient content of $\mathrm{HM}$
[26]. However, in this study, the presence of diseases and variations of BMI were not explored, and the relationship between the HM stage and the GA was not statistically significant when the milk energy value and the acidity degree were compared. Despite the result, the literature presents findings in which the HM of mothers of preterm infants tends to be more caloric when compared to those of full-term babies [27].

The presence of a HMCS in a hospital is a desirable condition to guarantee the availability of rHM to children in the NICU [18]. However, the benefits can be guaranteed provided that it presents adequate hygienic-sanitary standards, contributing to the maintenance of lactation and helping to reduce early weaning among preterm babies.

Among the limitations of this study, it is possible to highlight the lack of other similar studies in the literature to compare with the findings demonstrated here; the possible influence of the collection of samples on the energy value of $\mathrm{HM}$, since these samples were extracted from both breasts by an electric pump for 30 minutes; and the small number of samples, justified by the low number of visits by mothers to the HMCS; these mothers, in many cases, have difficulties in extracting the milk or even attending the hospital on a daily basis, discontinuing the offer of $\mathrm{rHM}$ to their hospitalized child.

However, individual health data, collected routinely and analyzed in a timely manner, provide opportunities for the development of innovative, efficient, and cost-effective research that may reflect clinical management decisions as well as in the planning of public health services, improving health care services for women [28].

\section{CONCLUSION}

The study showed that the raw human milk collected in the HMCS of the UH-UNIFESP is of excellent quality, since no contamination was found and no color alteration was identified, 
and the analyzed samples presented low acidity levels and a high energy content.

The breastfeeding protection policy, through $\mathrm{HMB}$ actions, will contribute to the reduction of the morbidity and mortality of preterm infants, provided that the quality of the distributed $\mathrm{rHM}$ is one of the main goals in the care of these children.

\section{CONTRIBUTORS}

MAS MORENO and KP COCA participated in the conception, design, analysis and interpretation, revision and approval of the final version of this article. LS CASTRO and ACFV ABRÃO participated in the analysis and interpretation, revision and approval of the final version of this article.

\section{REFERE N C E S}

1. Brasil. Presidência da República. Lei n¹1.346, de 15 de setembro de 2006. Cria o Sistema Nacional de Segurança Alimentar e Nutricional - SISAN com vistas em assegurar o direito humano à alimentação adequada e dá outras providências. Brasília: Diário Oficial da União; 2010.

2. Kepple AW, Segall-Corrêa AM. Conceituando e medindo segurança alimentar e nutricional. Ciênc Saúde Coletiva. 2011;16(1):187-99.

3. Word Health Organization. 10 facts on breastfeeding. 2014 [cited 2018 July 27]. Available from: http:// www.who.int/features/factfiles/breastfeeding/en/

4. Cordero MJA, García LB, López AMS, Barrilao RG, Rodríguez RH, Villar NM. Beneficios inmunológicos de la leche humana para la madre y el niño: revisión sistemática. Nutr Hosp. 2016;33(2). http:// dx.doi.org/10.20960/nh.526

5. Victora C, Bahl R, Barros A, França G, Horton $\mathrm{S}$, Krasevec J, et al. Breastfeeding in the 21st century: Epidemiology, mechanisms, and lifelong effect. Lancet. 2016;387(10017):475-90.

6. Brahm P, Valdés V. Beneficios de la lactancia materna y riesgos de no amamantar. Rev Chil Pediatr. 2017;88(1):7-14

7. Schanler R. Em tempo: leite humano é a estratégia alimentar para prevenir a enterocolite necrosante. Rev Paul Pediatr. 2015;33(2):131-3.

8. Pinheiro MC, Paludo J. Doação de leite humano em Unidade de Terapia Intensiva Neonatal: percepções das mães doadoras, dificuldades encon- tradas e fatores limitantes. Rev Bras Nutr Clin. 2015;30(3):211-5.

9. Paiva C, Saburido K, Vasconcelos M, Silva M. Breastfeeding a hospitalized newborn: Difficulties of mothers with children in neonatal intensive and intermediate care units. Rev Min Enferm. 2013;17(4):932-9.

10. Agência Nacional de Vigilância Sanitária. Banco de leite humano: funcionamento, prevenção e controle de riscos. Brasília: Anvisa; 2008 [acesso 2018 ago 2]. Disponível em: http://www.redeblh. fiocruz.br/media/HMBanv2008.pdf

11. World Health Organization. Guidelines on optimal feeding of low birth-weight infants in low- and middle-income countries. Geneva: WHO Press; 2011 [cited 2018 Aug 2]. Available from: http:// www.who.int/maternal_child_adolescent/ documents/9789241548366.pdf

12. Vieira AA, Moreira MEL, Rocha AD, Pimenta HP, Lucena SL. Análise do conteúdo energético do leite humano administrado a recém-nascidos de muito baixo peso ao nascimento. J Pediatr. 2004;80:490-4.

13. Novak F, Cordeiro D. The correlation between aerobic mesophilic microorganism counts and Dornic acidity in expressed human breastmilk. J Pediatr. 2007;83(1):87-91

14. Fundação Oswaldo Cruz. Normas técnicas REDEHMB-BR para Banco de Leite Humano. Rio de Janeiro: Fiocruz; 2005 [acesso 2018 ago 2]. Disponível em: http://www.redeblh.fiocruz.br/ media/seleclas.pdf

15. Blencowe H, Cousens S, Chou D, Oestergaard M, Say L, Moller A, et al. Born too soon: The global epidemiology of 15 million preterm births. Reprod Health. 2013;10(Suppl.1):S2.

16. Calil VMLT, Falcão MC. Composição do leite humano: o alimento ideal. Rev Med. 2003;82(1-4):1-10.

17. Moraes P, Oliveira M, Dalmas J. Perfil calórico do leite pasteurizado no banco de leite humano de um hospital escola. Rev Paul Pediatr. 2013;31(1):46-50.

18. Rede Global de Bancos de Leite Humano. NT 47.18: uso do leite humano cru exclusivo em ambiente neonatal. 2018 [acesso 2018 ago 2];1(47):1-16. Disponível em: http://www. sbp.com.br/fileadmin/user_upload/norma _tecnica_47.pdf

19. Bayramoglu A, Buruk K, Dinc U, Mutlu M, Yilmaz G, Aslan Y. Investigation of an outbreak of Serratia marcescens in a neonatal intensive care unit. J Microbiol Immunol Infect. 2011;44:111-5. http:// dx.doi.org/10.1016/j.jmii.2010.02.002 
20. Cavalcante J, Telles F, Peixoto M, Rodrigues R. Uso da acidez titulável para controle de qualidade do leite humano ordenhado. Ciênc Tecnol Aliment. 2005;(1):103-8.

21. Rona M, Novak F, Portilho M, Pelessari F, Martins A, Matiole G. Efeito do tempo e temperatura de estocagem nas determinações de acidez, cálcio, proteínas e lipídeos de doadoras de banco de leite humano. Rev Bras Saúde Matern Infant. 2008;8(3):257-63.

22. Bhisikar S, Mondkar J, Manerkar S, Goel S, D’Dsouza D, Baveja S. Improving quality of banked milk: Utility of Dornic acid test. Indian J Pediatr. 2018;85(4):272-5.

23. Grazziotin M, Grazziotin A, Vidal N, Freire M, Silva R. Analysis of the storage methods for raw human milk from mothers with infants admitted to a neonatal Intensive Care Unit, according to Brazilian regulations. J Hum Lact. 2016;32(3):446-54.

24. D'Amico CJ, DiNardo CA, Krystofiak S. Preventing contamination of breast pump kit attachments in the NICU. J Perinat Neonatal Nurs. 2003;17(2):150-7.

25. National Health and Medical Research Council. Infant feeding guidelines (2012). Canberra: National
Health and Medical Research Council; 2017 [cited 2017 Sep 11]. Available from: https://www.nhmrc. gov.au/sites/default/files/images/literature-reviewinfant-feeding-guidelines.pdf

26. Dritsakou K, Liosis G, Valsami G, Polychronopoulos E, Skouroliakou M. The impact of maternal and neonatal associated factors on human milk's macronutrients and energy. J Matern Fetal Neonatal Med. 2017;30(11):1302-8. http://dx.doi. org/10.1080/14767058.2016.1212329

27. Ballard O, Morrow AL. Human milk composition: Nutrients and bioactive factors. Pediatr Clin North Am. 2013 [citado em 2018 outubro 20];60(1):49-74. http://dx.doi.org/10.1016/j.pcl.2012.10.002

28. Benchimol El, Smeeth L, Guttmann A, Harron K, Hemkens LG, Moher D, et al. The Reporting of studies conducted using observational routinelycollected health data (RECORD) statement. Z Evid Fortbild Qual Gesundh wesen). 2016;115/116:33-48. http://dx.doi.org/10.1016/j.zefq.2016.07.010

Received: August 22, 2018

Final version: December 4, 2018 Approved: December 18,2018 